\title{
Variation in Soil Parameters in the Thaulla Area of Ulankulama Tank at Anuradhapura, Sri Lanka
}

\author{
Abeysingha N.S. ${ }^{*}$, Jayaneththi J.P.H.U. ${ }^{1}$, Kosgollegedara E.J. ${ }^{1}$ and Hammer S. ${ }^{2}$ \\ ${ }^{1}$ Rajarata University of Sri Lanka \\ ${ }^{2}$ College of General Studies, Boston University, Boston,United States \\ *nabeysingha@gmail.com
}

\begin{abstract}
Thaulla is the upper peripheral gentle sloping land in human-built irrigation reservoir-lakes ("tanks") of Sri Lanka. It is considered to play a significant role in filtering incoming water and absorbing nutrients. But, at present the thaulla area of most of the tanks has degraded and changed its land cover and land use. This study investigated the role of the thaulla area in Ulankulama Tank by observing the variation in 11 soil parameters including $\mathrm{pH}, \mathrm{EC}, \mathrm{N}, \mathrm{P}, \mathrm{K}$, $\mathrm{Ca}, \mathrm{Mg}, \mathrm{Na}$, sand, silt and clay content in soils. Soil samples were collected from 19 randomly selected points in the thaulla area $\left(\sim 0.43 \mathrm{Km}^{2}\right)$ from two depths $(0-15,15-30 \mathrm{~cm})$. These soil samples were tested for the above soil paramters using standard methods and point sample values were interpolated to the thaulla area using the interpolation method, Inverse Distance Weighting (IDW) in Arc GIS 10.2.
\end{abstract}

The results indicated that the thaulla area of the Ulankulama Tank acts approximately as a wetland as evidenced by the accumulation of $\mathrm{P}(1254 \mathrm{ppm})$ and recorded lower $\mathrm{N}(0.046 \%)$ content in thaulla area. Moreover, the thaulla area of this tank trapped elements such as $\mathrm{Mg}$, $\mathrm{Na}$, and $\mathrm{Ca}$ as shown by decreasing concentration in thaulla area towards the water spread area. This was especially evident though the south western portion where most of water flows through the grasses. The average exchangeable concentration of $\mathrm{Mg}, \mathrm{Na}$ and $\mathrm{Ca}$ varies from 34 to $122 \mathrm{ppm}, 11$ to $154 \mathrm{ppm}$, and 123 to $505 \mathrm{ppm}$ respectively in the thaulla area. Behavior of exchangeable concentration of $\mathrm{K}$ is different those of exchangeable $\mathrm{Mg}, \mathrm{Na}$ and $\mathrm{Ca}$. The concentration of $\mathrm{K}$ increases towards the water spread area of the tank. However, $\mathrm{K}$ concentration changed from 3 to $19 \mathrm{ppm}$ only with a CV of 0.54 . Clay and silt percentages are comparatively higher in places where grasses are concentrated. The results of this study could be helpful in rehabilitation and management of tank ecosystem in tank cascade systems of Sri Lanka.

Keywords: Constructed wetland, Thaulla, Tank cascade system, Ulankulama tank

Proceedings of the International Forestry and Environment Symposium 2016, Department of Forestry and Environmental Science, University of Sri Jayewardenepura, Sri Lanka. 